DOI: doi.org/10.21009/IJLECR.071.07

Received: 20 October 2020

Revised: 21 December 2020

Accepted: 18 June 2021

Published: 30 June 2021

\title{
FLOUTING MAXIM ON UTTERANCE OF CHARACTERS IN "ANAK NEGERI (KISAH MASA KECIL GANJAR PRANOWO)" MOVIE
}

\author{
Rina Husnaini Febriyanti ${ }^{1, a)}$ \\ State University of Jakarta ${ }^{1)}$ \\ rhfebriyanti@gmail.com ${ }^{\text {a) }}$
}

\begin{abstract}
Implicature utterance that was introduced by Grice and his categorization on maxims those are quantity, quality, relevance, and manner seem interested to be studied, as the aim of this study is to find out the flouting of Grice maxims. The Method used was qualitive and data was collected from the utterances of the characters in "Anak Negeri (Kisah Masa Kecil Ganjar Pranowo)" Movie afterwards the data were categorized based on flouting maxims then displayed into percentage and reflected involved the reasons of those flouting maxims. Next, it was analyzed and presented in description explanation. The results found that the most flouting occurred is flouting of maxim quantity that is $46 \%$ where there are several reasons, they are in order to convince, to elaborate, to permit, and to empathy. And in the same time, the flouting of maxim relevance is not too far with quantity that is $41 \%$ with the purpose of using these flouting maxims are to inform, to give idea, to ask back, to calm down, to wonder, and to complement. Flouting of maxim quality is $5 \%$ and the reason found is to explain, while flouting of maxim manner is $5 \%$ too and the reason was to ask meaning. In other words, those flouting maxims occur, it must have a purpose, and depend on the context where this study is viewed in pragmatics perspective.
\end{abstract}

Keywords: Flouting Grice's Maxims, Flouting Maxim of Quantity, Flouting Maxim of Quality, Flouting Maxim of Relevance, Flouting Maxim of Manner

Language is a system that is used by human to communicate each other among them. As stated by (Morris, 2007) "Language is a system of signs which we use to communicate with each other. Communication is a matter of letting other people know what we think." In other words, applying a language means describing what human thought and how that thought is delivered to other human or hearer. Whatever the form of the language and how it is used as communication tool, it has purpose and meaning to be understood.

Using a language does not go far from meaning, purpose, and context, and to whom that it is used and toward whom it is delivered. The existence of the language almost all are influenced by socio-culture of the speaker and hearer. For instance, language in political and entertainment context are different. Travis in (Wright, 1998) said that "Pragmatics is the study of properties of words which depend on their having been spoken, or reacted to, in a certain way, or in certain conditions, or in the way, or conditions, they were." It can be summed up that language is used in a context, situation and purpose to dig deeper from the utterance is such kind of Pragmatics proposed.

In delivering language utterance sometimes is spoken in explicitly or implicitly for reason. 
Grice divided into two kinds of utterances those are conventional and non-conventional utterance. In conventional utterance means it is talked as true as the meaning while non-conventional is uttered in implicitly or Grice called this as implicature. (Potts, 2015) Conversational implicatures are the centerpiece of Gricean pragmatics and its subsequent developments. On Grice's conception, they require speakers to reason not only in terms of their language but also their understanding of the context and each other's goals and intentions. This places conversational implicatures at the center of debates about the distinction between semantics and pragmatics and guarantees them a leading role in investigations of language and social cognition.(Chapman, 2005) Grice uses the simple notion of cooperation, together with the more elaborate structure of categories, to offer a systematic account of the many ways in which literal and implied meaning, or 'what is said' and 'what is implicated'. The noun 'implicature' and verb 'implicate' (as used in relation to that noun) are now familiar in the discussion of pragmatic meaning, but they were coined by Grice, and coined late on in the development of his theory. In early work on conversation he suggested that a 'special kind of implication' could be used to account for differences between conventional meaning and speaker meaning. He ultimately found this formulation inadequate, together with a host of other words such as 'suggest', 'hint' and even 'mean', precisely because of their complex pre-existing usage both within and outside philosophy.

In (Grice, 1990) Grice explained about the cooperative principle that means make the contribution as is required, when it is required, by the conversation in which it is engaged. And, he categorized the maxims into the four following items a) Quality: Contribute only what you know to be true. Do not say false things. Do not say things for which you lack evidence, b) Quantity: Make your contribution as informative as is required. Do not say more than is required, c) Relation (Relevance): Make your contribution relevant, and d) Manner: (i) Avoid obscurity; (ii) avoid ambiguity; (iii) be brief; (iv) be orderly. Grice analogue for each of maxims such as: 1) Quantity. If you are assisting me to mend a car, I expect your contribution to be neither more nor less than is required. If, for example, at a particular stage I need four screws, I expect you to hand me four, rather than two or six. 2) Quality. I expect your contributions to be genuine and not spurious. If I need sugar as an ingredient in the cake you are assisting me to make, I do not expect you to hand me salt; if I need a spoon, I do not expect a trick spoon made of rubber. 3)Relation. I expect a partner's contribution to be appropriate to immediate need at each stage of the transaction. If I am mixing ingredients for a cake, I do not expect to be handed a good book, or even an oven cloth (though this might be an appropriate contribution at a later stage), and 4) Manner. I expect a partner to make it clear what contribution he is making and to execute his performance with reasonable dispatch. He also explained that a participant in talk exchange may fail to fulfill a maxim in various ways, which include the following: 1) He may quietly and unostentatiously violate a maxim: if so, in some cases he will be able liable to mislead, 2) He may opt out from the operation both of maxim and of the cooperative principle; he may say, indicate, or allow it to become plain that he is unwilling to cooperate in the way the maxim requires, 3)He may be faced by a clash: he may be unable, for example, to fulfill the first maxim of quantity (be as informative as is required) without violating the second maxim of quality have adequate evidence for what you say), and 4) He may flout a maxim; that is, he may blatantly fail to fulfill it.

There were several studies that also analyzed about Grice's maxims such as (Tajabadi ${ }^{\mathrm{a}}$, Dowlatabadi, \& Mehri, 2014) their studied focusing on the use of Grice's cooperative maxims in oral arguments with the intention of finding out what cooperative maxims are more frequently abided and what maxims are more frequently violated by Persian speakers engaged in oral disputes in Iranian Dispute Settlement Council, and they found that "quantity" and "relevance" were the two maxims more frequently violated during the disputes. Additionally, maxim of "quality" and "manner" were the ones most followed. (Ephratt, 2012) he analyzed the addresser's failure to 
satisfy Grice's cooperative principle, or whether when seen as meaningful symbols, such cases can be seen as complying with the cooperative principle, and found highlight the active role played by verbal silence in communication.(Ayasreh \& Razali, 2018) he illustrated some maxims that were flouted by the Syrian leader, Bashar Al-Assad during his interview with the ARD channel. Analysis of the maxims of the Arab leader's interview revealed that the main reason for Assad's violation of the maxims was to convey meanings in his favor. It can be implicated that political leaders flout maxims to produce particular shades of meanings which may not always be conceivable to all parties in order to gain the support from masses.(Fukumura \& Gompel, 2017) they proposed that initial referential processing was led by the lexicon-semantic representation of the referring expression rather than Gricean expectations about optimal informativeness: Redundancy of a size modifier immediately disrupted comprehension because the processor failed to activate the referential contrast implied by the meaning of the modifier, whereas referential ambiguity had no immediate effect, as it allowed the activation of at least one semantically-compatible referent. (Vergis, 2017) he sought to examine flouts of the Maxim of Quality and relativized face concerns, and their effect on speaker meaning. Results of the experiment reported here revealed that flouts of Quality produced inferences in the predicted direction (friendly, teasing readings) but perception of aspects of speaker meaning was also affected as a function of (strong or minimal) face sensitivities.(Yoon \& Frank, 2019) their work used a time-sensitive tablet paradigm, they examined developmental gains in children's ad hoc implicature processing and found evidence for successful pragmatic inferences by children as young as 3 years in a supportive context and substantial developmental gains in inference computation from 2 to 5 years. They also tested whether one cause of younger children's (2-year-olds) consistent failure to make pragmatic inferences was their difficulty in inhibiting an alternative interpretation that was more salient than the target meaning (the salience hypothesis). Their findings supported the hypothesis; younger children's failures with pragmatic inferences were related to effects of the salience mismatch between possible interpretations.

"Anak Negeri (Kisah Masa Kecil Ganjar Pranowo)" movie was released in 2018 and directed by Andika Prabangkara, it was adopted from novel with similar title that was written by Gatotkoco Suroso, and the story tells about the childhood of Ganjar that he and his family struggled of surviving their life. The setting of the movie is in central Java with identically in bold Javanese culture. The places are taken from Karanganyar, Boyolali, and Yogyakarta. This movie contains of 10 chapters, and each of the chapters from when Ganjar began his school in primary school to university. There are 10 of major characters and 25 minor characters from Yogyakarta Theatre Community. The story is based on the true story with about $90 \%$ of similarity. Uniquely, the story in bilingual that is in Bahasa Indonesia and Javanese where the utterances by the characters contain explicit and implicitly ways. Therefore, the current study tries to find out from pragmatics perspective that is focused on flouting Grice maxims on utterance of characters in "Anak Negeri (Kisah Masa Kecil Ganjar Pranowo)" movie.

\section{METHOD}

This study used qualitative method to describe flouting Grice maxims on utterance of characters in "Anak Negeri (Kisah Masa Kecil Ganjar Pranowo)" movie. The data was taken from the utterances of dialogues among characters. The data collection was by categorizing the flouting Grice maxims those are flouting on quality, quantity, relevance, and manner, also applying some reasons that caused of maxims flouted. Technically, data were taken note to identify based on the categorization and then reflected on notes to find out the reasons of maxim flouted afterwards data was analyzed, then presented in percent form, and explained into description. 


\section{RESULTS AND DISCUSSION}

The results of this current study present into for categorization of flouting Grice's maxims that each of the categorizations involved the reasons of why the implicatures occurred. The total result can be displayed in the following table:

\begin{tabular}{|l|c|c|}
\hline Categorization of Flouting Maxim & Total Amount of Times & Percentage \\
\hline Flouting Maxim of Quantity & 19 Times & $46 \%$ \\
\hline Flouting Maxim of Quality & 2 Times & $5 \%$ \\
\hline Flouting Maxim of Relevance & 17 Times & $41 \%$ \\
\hline Flouting Maxim of Manner & 3 Times & $7 \%$ \\
\hline
\end{tabular}

In related the occurrence of flouting maxims they came from several reasons that as the purpose on uttering that will be discussed on each of its categorizations.

1. Flouting Maxim of Quantity

In this flouting, the utterance that were found several reasons in order to reply the questions of the speaker such as to convince, to elaborate, to permit, and to empathy. Firstly, for to convince it can be seen from the following conversation:

Teman Ganjar: "Sekolahmu tetep neng kene to?"

(Ganjar's Friend : "Does your school still here?")

Ganjar: "Isihlah lah meh arep neng endi"

(Ganjar: "Yes, where should I school then?")

The utterance of "Yes, where should I school then?" means additional information that it is supposed to be in effectively can be answered just by saying "yes" but it appears in order to convince Ganjar's friend that he doesn't go to school anywhere. Secondly, the reason is to elaborate answer as follows:

Ayah Ganjar: "Tak terasa anak-anak sudah besar ya Bu?"

(Ganjar's Father: "It can't be felt that the children have grown up already yes mom?")

Ibu Ganjar:"iya pak Joko itu sudah mau lulus, Wati itu sudah SMA, dan Ganjar tau-tau sudah SMP lho Pak"

(Ganjar's mother: "Yes Pak, Joko will graduate, Wati has already in Senior High

School, and Ganjar is just suddenly in Junior High School, Pak")

The utterance of "Yes, Joko will graduate, Wati has already in Senior High School, and Ganjar is suddenly in Junior High School” is quietly long explanation that is explained in order to elaborate in detail answer of the question where actually it can be answered with "yes" only. However, the answer is to agree or exclaim the question by giving detail description of their children have been grown with countless time. Thirdly, the reason is to permit within the conversation as follows:

Mbak Ika: " Gini lho Njar, Bapak Ibu sudah menyampaikan rencana kami yah kami Cuma mau memastikan saja kalo Ganjar mau bersekolah di Yogya"

(Ika as Ganjar's Sister in Law: "Just like this Njar, Father and Mother has informed about our plan and we just to make sure that Ganjar wants to school in Yogya")

Ganjar: "Mau mas, mbak, asalkan Bapak sama Ibu mengijinkan"

(Ganjar: "Yes I want Sister and Brother, if Father and Mother let me go")

The way of Ganjar's answer showed that he agreed within permission of his parent in order to imply his respectfulness towards his parents that as a son or child will not go anywhere without the parent's blessing or permit. Lastly, the reason is to empathy that it 
can be illustrated in the following conversation between Ganjar and his sister in law namely Ika:

Ganjar:"Mbak saya diterima di UGM."

(Ganjar:" Sis, I was accepted in UGM.")

Mbak Ika:"Syukur panjaban kamu dijabahi karo Gusti Allah, mbak melu seneng

ora sio-sio leh mempeng sinau mengko ngomong karo masmu ndelok engkas muleh."

(Ika as Ganjar's Sister in Law: "Grateful for you that your praying came true by Allah, Sister feels happy too that your studying was not useless after this you may talk to your brother that he almost will go home after this."

Ganja's sister in law expressed "Grateful for you that your praying came true by Allah, Sister feels happy too that your studying was not useless after this you may talk to your brother that he almost will go home after this." Meaning that she also feels empathy of the acceptance in UGM on Ganjar as she also his family feels happy and proud because she in keep contributing on Ganjar's study and fulfilling his life.

2. Flouting Maxim of Quality

The reasons in this flouting as not many as in the previous one that is flouting in quantity maxim that the utterance amount was only found into two dialogues and both have similar reasons those purpose in order to explain, and the conversations are in the following:

Ganjar:"Dek Atiq maaf, ya."

(Ganjar: "Dek Atiq I'm sorry, yes.")

Atiq:" Wah maaf mas Ganjar itu banyak sekali ya?"

(Atiq: “Ups, Mas Ganjar's apologizes are so many yea?”)

The reason of Atiq explains to Ganjar in order to show disappointing towards him that he rarely visited Atiq as her girlfriend. Therefore, she said about the amount of apologize where it can't be counted or calculated. It is such a kind of statement that to show she expects more being visited implicitly in a lie or stated intentionally in false way. Another flouting maxim of quality is as follows:

Keponkaan Ganjar:" Om ibu lagi ke surga ya, aku juga mau pergi kesana Om."

(Ganjar's niece: "Uncle, my mom is going to heaven yea, I want to go there too Uncle.")

Ganjar:"Kalo ke surga ga boleh bareng bareng sayang."

(Ganjar: "If we go to heaven, we can't go together dear.")

Ganjar's explanation towards his niece in purpose to make her not feeling sad on the death of her mother so he said in untrue answer intentionally. It can be said that his statement in order to comfort his niece. Therefore, he expressed towards his nice in dishonest.

3. Flouting Maxim of Relevance

There are some reasons in flouting maxim of relevance they are to inform, to give idea, to ask back, to calm down, to wonder, and to complement. The utterances are as follows:

Ibu Ganjar: "yowes sekarang kamu mandi dulu"

(Ganjar's mother: "Alright, you may go to take a bath now."

Ganjar:" nggih bu tapi adem bu" (iya bu tapi dingin)

(Ganjar:" Alright mom, but it's cold mom."

Ganjar's answer is irrelevant with his mother's question that asking to get taking a bath, but he answered by saying different about cold water, while it can be answered yes or later to be relevant.

Ganjar: "Arep dolan nengdi?"

(Ganjar: "Where will we play?") 
Teman Ganjar: "Bakar jagung wae Bapak lagi panen"

(Ganjar's Friend: "Grill the corn my father has harvested it.")

The utterance of Ganjar's friend is irrelevant towards the Ganjar's question that he didn't answer the question where they to go to play, yet he said, "Grill the corn my father has harvested it." Meaning he gave idea to do an activity of grilling where it didn't a such kind of playing. Additionally, the question was asking about "Where will we play?" in relevantly it may answer about some places to go for playing, not an activity.

Ibu Ganjar:" Oh ya pak bagaimana tawaran Mbak Ika dan Kunto untuk menyekolahkan Ganjar di Yogya?"

(Ganjar's Mother: "Oh yea Pak, How about the offering from Mbak Ika and Kunto for schooling Ganjar in Yogya?")

Ayah Ganjar:" Tapi Ganjar sendiri, Bagaimana, Bu?"

(Ganjar's Father: "But how about Ganjar himself, Bu?")

The way of Ganjar's father in answering his wife precisely doesn't answer her question, but he asks back to his wife and it can't be answered by his wife too, because the answer will invite third person that one is their son (Ganjar). Hence, this kind of statement irrelevant answer by the question.

Ibu Ganjar: " Suoro opo to iku pak?"

(Ganjar's Mother: "What sound was that, Pak?")

Ayah Ganjar: "wes...wes ... tenang..tenang."

(Ganjar's Father: "OK...OK... calming down...calming down.”)

Ganjar's mother question about the sound, while her husband answered not about it but in order to make his wife not being afraid because of the sound. It is irrelevant utterance towards the question, but behind the answer there is implicit purpose in order to calm down.

Ganjar: "Cah mulai sekarang, kita harus berpikir sebelum bertindak karena keinginan pribadi itu bisa membahayakan orang lain."

(Ganjar: "Guys from now, we have to think before to do because personal eager may danger other."

Teman Ganjar: " Kamu kok tiba-tiba jadi bijaksana gini to Njar?"

(Ganjar's Friend:"How come you become a wise like this , Njar?")

Ganjar's friend utterance showed that he wondered on Ganjar's thought, but he didn't reply towards what Ganjar was discussed about that being a man couldn't do as he wanted but should thought about the risk and others. Hence, the utterance of Ganjar's friend is irrelevant because it doesn't relate, but it seems to wonder about the way of Ganjar's thought.

Bapak Mbak Ika:" Kini kembang desa itu tergeletak tak berdaya karena kanker menggerogoti tubuhnya"

(Mbak Ika's Father: "Now that uptown girl lied down paralyzed because cancer undermines her body.")

Ganjar:" Tapi kanker itu tidak akan bisa menggerogoti kecantikan hatinya."

(Ganjar:" But that cancer will not undermine the beautiful of her heart.")

The response of Ganjar is irrelevant towards the statement of "Now that uptown girl lied down paralyzed because cancer undermines her body." Because he opened another perception about Mbak Ika's description implicitly that the kindness of her will not lost, where the first statement was discussed about Mbak Ika's concrete physical condition where she was sick.

4. Flouting Maxim of Manner

In this flouting maxim of Manner, there are only three dialogues where all the purposes are similar those are in order to ask meaning, and one of dialogues as follows: 
Ganjar:"Doh ciloko ak kesoren"

(Ganjar: "Doh, it's terrible I was too evening.")

Teman Ganjar:" Opone Njar?"

(Ganjar's Friend: "What was that, Njar?")

Ganjar: "Dolanku kesoren ndak dijewer bapakku aku"

(Ganjar: "My playing it's too evening, my ears will be pinched by my father.")

Ganjar's utterance expressed an ambiguity of Ganjar: "Auw, it's terrible I was too evening.") when he said it, his friend didn't understand what it was meant because when it was too evening, it was still unclear to be understood, hence, he asked again towards Ganjar what its meaning. Here, Ganjar indicated time that when it was too evening, he would be punished by his father but he and his father who knew its context only, while others not.

\section{CONCLUSION}

In sum up this study, the flouting Grice maxims on utterance of characters in "Anak Negeri (Kisah Masa Kecil Ganjar Pranowo)" show that the most flouting occurred is flouting of maxim quantity where there are several reasons, they are in order to convince, to elaborate, to permit, and to empathy. And in the same time, the flouting of maxim relevance is not too far with quantity with the purpose of using these flouting maxims are to inform, to give idea, to ask back, to calm down, to wonder, and to complement. In other words, those flouting occur it must have a purpose, and depend on the context where this study is viewed in pragmatics perspective. The distinctive from the previous studies such as Ayasreh and Razali, Ephratt, Tajabadi, and Yoon were almost similar in Grice's perspective, yet in different focus and different object of the study. In further study, it may be analyzed in sociolinguistics perspective whereas this study happens in Javanese culture.

\section{REFERENCES}

Ayasreh, A., \& Razali, R. (2018). The Flouting of Grice' s Conversational Maxim : Examples from Bashar Al- Assad's Interview during the Arab Spring. 23(5), 43-47. https://doi.org/10.9790/0837-2305014347

Chapman, S. (2005). Paul Grice: Philosopher and linguist. Paul Grice: Philosopher and Linguist, 1247. https://doi.org/10.1057/9780230005853

Ephratt, M. (2012). Language \& Communication "“ We try harder "' - Silence and Grice 's cooperative principle , maxims and implicatures. Language and Communication, 32(1), 62-79. https://doi.org/10.1016/j.langcom.2011.09.001

Fukumura, K., \& Gompel, R. P. G. Van. (2017). How do violations of Gricean maxims affect reading ? Journal of Memory and Language, 95, 1-18. https://doi.org/10.1016/j.jml.2017.01.008

Grice, P. (1990). Studies in the Way of Words By Paul Grice Harvard University Press, 1989, 385 pp., £25.95. Philosophy, Vol. 65, pp. 111-113. https://doi.org/10.1017/s0031819100064330

Morris, M. (2007). An Introduction to the Philosophy of Language. New York: Cambridge University Press.

Potts, C. (2015). Presupposition and Implicature. The Handbook of Contemporary Semantic Theory, (June), 168-202. https://doi.org/10.1002/9781118882139.ch6

Tajabadi ${ }^{a}$, A., Dowlatabadi, H., \& Mehri, E. (2014). Grice's Cooperative Maxims in Oral Arguments : The Case of Dispute Settlement Councils in Iran. Procedia - Social and Behavioral Sciences, 98(1975), 1859-1865. https://doi.org/10.1016/j.sbspro.2014.03.616

Vergis, N. (2017). ScienceDirect The interaction of the Maxim of Quality and face concerns : An experimental approach using the vignette technique. Journal of Pragmatics, 118, 38-50. https://doi.org/10.1016/j.pragma.2017.07.009 
Wright, B. H. and C. (1998). A Companion To The Philosophy of Language. In Journal of Chemical Information and Modeling (Vol. 53). https://doi.org/10.1017/CBO9781107415324.004

Yoon, E. J., \& Frank, M. C. (2019). Journal of Experimental Child The role of salience in young children' s processing of ad hoc implicatures. Journal of Experimental Child Psychology, 186, 99-116. https://doi.org/10.1016/j.jecp.2019.04.008 